\title{
The Research of an Evaluation Indicator System Design for the Core Competitiveness of Aerospace Enterprises from a Dual Capacity Perspective
}

\author{
LI Dong $^{1, a, *}$, ZHENG Chu-gui ${ }^{2, b}$, ZHANG Yun-tang ${ }^{1, c}$ \\ 1. School of Management, Harbin Institute of Technology, P.R.China, 150001 \\ 2. The Third Academic, China Aerospace Science \& Industry Corp, P.R.China, 100074 \\ a sxlidong5858@126.com, ${ }^{\mathrm{b}}$ zhengchugui2010@sohu.com, ${ }^{\mathrm{c}}$ zhangyuntang1986@126.com \\ *corresponding author
}

Keywords: dual capacity; aerospace enterprise; core competitiveness; evaluation indicator

\begin{abstract}
Through comprehensive analysis of Chinese and foreign literature on the core competitiveness of aerospace enterprises, the factors influencing the core competitiveness of aerospace enterprises in China are summarized, followed by the analysis made based on such elements as the resource capacity, technical capacity, product capacity and environment capacity of aerospace enterprises. From a dual-capacity perspective, a model for identification of the factors influencing the core competitiveness of aerospace enterprises is constructed, with thirteen influencing factors selected by means of expert questionnaire survey, with evaluation of each indicator conducted respectively, followed by screening based on the importance of each influencing factor, with four capacities and eight indicator factors relating to the core competitiveness of aerospace enterprises from a dual-capacity perspective finally selected.
\end{abstract}

\section{Introduction}

The projects undertaken by the aerospace enterprises in China reflect China's national strength, and aerospace enterprises shoulder the important task of exploring the mystery of the universe. Currently, in terms of aerospace technology, the western countries represented by America and Russia are the first echelon, and have leading advantages; China is the second echelon, and it is necessary for China's aerospace enterprises to learn advanced technology from western countries, but they should pay more attention of the research and development of their own technology ${ }^{[1]}$. Presently, China's independent innovation capacity is in the middle and lower level, ranking 28th among 49 advanced countries in the world, with a low innovation level, with no technology monopoly formed $^{[2]}$. Western countries have been implementing technological lock-in against China in term of aerospace technology, so only by insisting on independent innovation and self-reliance and forming their own technology monopoly advantages, can China's aerospace enterprises be in the invincible position in the aerospace competition.

Core competitiveness, as drive for the sustainable development of aerospace enterprises, plays a supporting role ${ }^{[3]}$. Once core competitiveness is formed, it will have certain stability, and go through dynamic changes at the same time ${ }^{[4]}$. With the constant development of enterprises, as for the core competitiveness of general enterprises, the competitive advantages of a certain competitive power may be lost, reducing the core competitiveness of such enterprises to ordinary competitiveness and even contributing to the loss of enterprise competitiveness ${ }^{[5]}$. In the process of 
constant development of enterprises, the largest difference from other ordinary enterprises is the core competitiveness of aerospace enterprises shows a multi-business development trend, which means that aerospace enterprises have a certain core competitive power in their main business filed and adopt a multi-business forms to support the overall development of aerospace enterprises ${ }^{[6]}$. Therefore, to possess long-term core competitiveness, aerospace enterprises must constantly conduct innovative activities, rearrange and position their core resources of various kinds and define their multi-business fields based on the development direction of aerospace technology and the updating trend of the management and operation mode and technical talents aerospace enterprises ${ }^{[7]}$.

\section{Effect of military-to-civil strategy on aerospace enterprise}

The conversion from military to civil use that is involved in aerospace enterprises is the product of China being in peacetime and having been in such a particular period of history for a long time ${ }^{[8]}$. The military-to-civil conversion of aerospace enterprises is an economic activity, and also transfers of productivity, with the aim to covert surplus military productivity to the production of civilian products. The indirect application of aerospace technology provides technical guarantee for this economic activity, and this technology involves indirect application of aerospace technology to the civil industry to promote the development of the civil industry and the benefits and quality of production and operation of the civil industry ${ }^{[9]}$. The implementation of the military-to-civil strategy in China provides strategic support and realization path for the multi-business operation of aerospace enterprises. Based on the military-to-civil strategy, aerospace enterprises can selectively develop a new military-to-civil mode technically based on the different consumption needs of aerospace enterprises; develop different pricing methods, sales strategies and service forms based on different industry characteristics ${ }^{[10]}$. Aerospace enterprises are high-tech enterprises, with their technology featuring strong economic promotion, a variety of uses and strong adaptation not only in the military field but also in civil and commercial fields. The technologies used in the aerospace industry, including advanced material technology, thermal technology, control technology, computer technology, low- temperature technology, chemical industry technology, communication technology, radar technology and satellite technology, have broad application prospects in civil and commercial fields ${ }^{[11]}$. In peacetime, the military product production quantity of aerospace enterprises in China has decreased a lot, compared with that in times of war, causing aerospace enterprises to suffer reduced production, personnel loss and even near-bankruptcy, which accelerate the military-to-civil implementation progress of aerospace enterprises to a certain degree ${ }^{[12]}$. China's aerospace enterprises have developed new aerospace products and services, with rockets, satellites and weapons research and development as basis, with rocket launchers, space satellites and weapons as pillar industries ${ }^{[13]}$. The most direct result of application of the achievements of satellite technology to the national economy is the television relay industry, with the rapid development of the television relay industry promoted and the development space and commercial potential of the television industry further expanded. Aerospace enterprises' adoption of diversified operation strategy means their development and production of civil products using their own wide range of technologies and complete range of production equipment to avoid losses caused by insufficient order quantity due to simply relying on aerospace products ${ }^{[14]}$.

\section{Factors influencing the core competitive-ness from a dual-capacity perspective}

Through sorting-out and collection of Chinese and foreign literature in recent years, we adopt a literature research method to analyze the core competitiveness of aerospace enterprises, summarize the framework and indicators comprising the core competitiveness elements of aerospace enterprises and study whether these indicators are associated with the development of aerospace 
enterprises from the dual-capacity perspective of aerospace enterprises ${ }^{[15]}$. The analysis shows that from a dual-capacity perspective, the factors influencing the core competitiveness of aerospace enterprises in China mainly include resource factors, technical factors, product factors and environment factors, and the relationships between these factors and the core competitiveness of aerospace enterprises can be expressed with Fig. 1

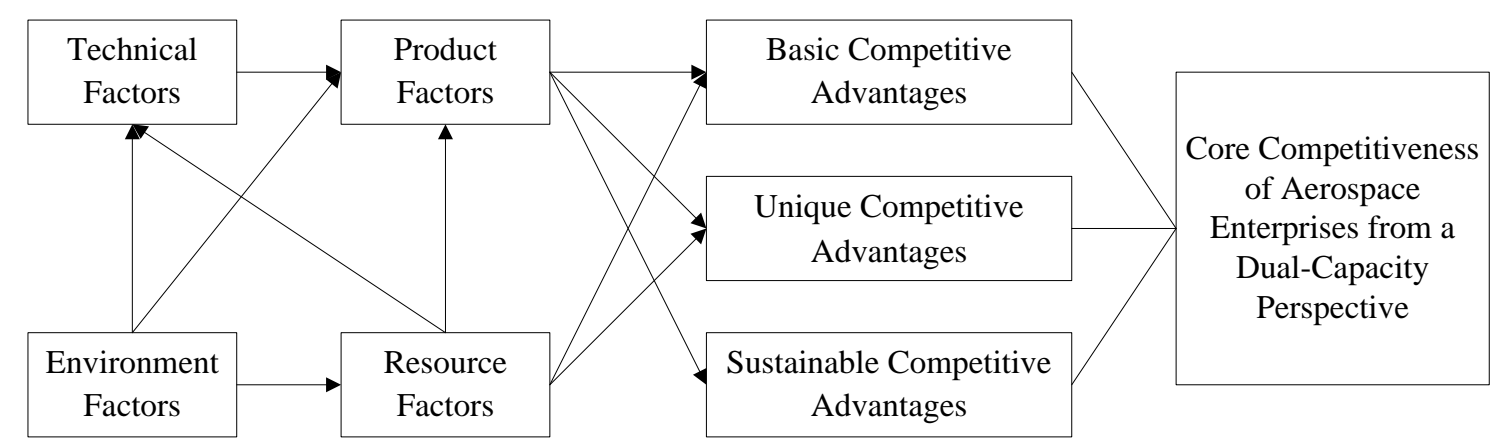

Fig. 1 Interrelationships between the factors influencing the core competitiveness of aerospace enterprises

\subsection{Resource factor}

The resource factors involve talent resources, market resources, funds management and renewable resources.

(1) Talent resources

By 2015, among 250,000 in-service employees inside the state-owned aerospace enterprises in China, management talents occupied 1/6, professional technical talents occupied 1/3 and skilled talents occupied 1/2. To date, among the employees in the state-owned aerospace enterprises in China, 5 have obtained "Two Missiles and One Satellite" merit medal, 30 are academicians of the Chinese Academy of Sciences and the Chinese Academy of Engineering, 26 are state-level experts, 15 are national professional technical outstanding talents, 5 have obtained Chinese science and technology awards, 140 are national candidates for the Hundred, Thousand and Ten Thousand Talent Project, 12 are national defense technology and industry award winners, 15 are "China Skill Award" winners, 171 have been granted the title "National Technical Expert" , 4599 experts have enjoyed special government allowances successively, and a large number of employees are provincial and ministerial-level talents.

(2) Market resources

Market resources are divided into two parts, internal market resources and external market resources, with internal market resources including product resources and fund resources and external market resources including brand resources, market demand resources, trading mode resources and market region resources. Internal market resources are closely bound up with enterprise business processes and possessed by enterprises and external market resources exist in the market and need to be obtained by enterprises through constant competitions.

(3) Fund management

Fund management can improve financial situation and comprehensive strength of aerospace enterprises to make them more competitive in the industry. China's aerospace enterprises meet their technical demands through capital expansion and increase in technical innovation funds. Sufficient funds can promote the R\&D work of enterprises so that they can obtain products with more high-tech content and actively explore and create a more effective sales and marketing network 
involving domestic and overseas markets to form competitive advantages and stabilizing their international standing.

(4) Renewable resources

China's aerospace enterprises need to consume a lot of resources in the development process and the equipment manufacturing industries relating to them produce some pollutants. Aerospace enterprises need to enhance the utilization of waste while implementing energy conservation and emission reduction to minimize the sources of pollution and waste in the production process, thereby realizing environment-friendly operation and developing cyclic economy. Aerospace enterprises, as China's national defense force, are obliged to assume responsibility for environmental management and ecological balance maintenance, so the recycling and utilization of renewable resources are important contents in the development process of aerospace enterprises. Aerospace enterprises have adopted resource recycling technology to reduce the emission of pollutants, increased the rate of resource utilization and provided enterprises with competitive advantages in many aspects in order to obtain more competitive advantages internationally, China's aerospace enterprises still need to comprehensively utilize renewable resources to a large degree.

\subsection{Technical factors}

China's aerospace enterprises have been in a situation where aerospace enterprises have been trying to reach the world's advanced aerospace technology level. Due to the late startup of China's aerospace technology and the technological lock-in implemented by Western countries, China's aerospace technology has developed slowly due to total reliance on independent research and development. The rapid development of space technology and relevant technological changes in the world has produced a great effect on the development and progress of aerospace enterprises in the world. Technical innovation can greatly influence the products, services, market, customers, suppliers and competitors of enterprises. If an enterprise continues to develop new technology, advance the application of new technology and speed up the research and development of products with independent intellectual property rights, the enterprise can greatly improve its sustainable development capacity. Under the current situation of development, only technical innovation of aerospace enterprises is the important support for the formation of their core competitiveness.

\subsection{Product factors}

Maintaining the development and core competitiveness of China's aerospace enterprises requires their good judgment of the market for their own products and good performance quality advantages, and important factors influencing the development of the core competitiveness of aerospace enterprises are product factors.

(1) The added value of products is the ultimate reliance of the added value of the core competitiveness of aerospace enterprises

Competitive advantages have unique performance and cost competitiveness, and high-quality products ultimately depend on products creating value for consumers and meeting market demands ${ }^{[28]}$. If the products manufactured by an enterprise are not competitive, such products will not have any value in actual use. Therefore, we should focus on the performance and quality of the core products of aerospace enterprises.

(2) The competitiveness in the market is the fundamental way to increase the economic benefits of aerospace enterprises

The economic benefits of China's aerospace enterprises involve actual benefits and long-term benefits. Actual benefits refer to the benefits that can be immediately realized and demonstrated in the current period, while long-term benefits require enterprises’ patience, long-term vision and 
strategies and are where the true value of core competitiveness of aerospace enterprises lies. Particularly, in the development situation of aerospace enterprises, good market judgment is the key to realizing the durable competitive advantages of aerospace enterprises. Therefore, enhancing the competitiveness of the products manufactured by China's aerospace enterprises in the market is the fundamental way of increasing economic benefits.

\subsection{Environment factors}

In the current development situation of enterprises, there are many factors influencing the development of China's aerospace development and all factors relating to the production and operation of enterprises have effect on the development of aerospace enterprises. In this paper, the main environment factors influencing the development of aerospace enterprises are divided into internal environment factors and external environment factors for analysis.

(1) Internal environment

Internal environment factors relating to the development of core competitiveness of aerospace enterprises involve the percentage of the contracts completed by enterprises and technical service conditions of enterprises. The percentage of the contracts completed by enterprises is the ratio of the number of the contracts completed to the total number of contracts. The technical service conditions of enterprises refer to the degree of perfection of computer network conditions used by enterprises during technical services.

(2) External environment

Among external environment factors, the development of the core competitiveness of China's aerospace enterprises contains all directly and indirectly -related external forces ,i.e. influencing factors for various external conditions for strengthening the core competitiveness of China's aerospace enterprises. The external environment factors influencing the development of the core competitiveness of aerospace enterprises mainly include enterprises obtaining government support and intellectual property protection. Enterprises obtaining government support means refers to the degree to which a certain aerospace enterprise obtains national support in terms of policies, technological renovation, finance and taxes.

\section{Selection of factors influencing the core competitiveness}

Through the analysis of the factors influencing the core competitiveness of China's aerospace enterprises from a dual-capacity perspective, the factors in the following four aspects can be obtained: resource factors, technical factor, product factors and environment factors, all of which comprise the core competitiveness of aerospace enterprises. Through the comprehensive analysis of domestic and foreign literature, coupled with the actual evaluation of the core competitiveness of China's aerospace enterprises, based on the design principle of survey questionnaires, relevant influencing factors are collected and sorted out. In this paper, an empirical analysis method is planned to be adopted to conduct careful screening of 13 constituent elements. The questionnaire survey is intended to analyze the degree of importance of the elements influencing the core competitiveness of aerospace enterprises from a dual-capacity perspective. This survey questionnaire package involves designing 13 indicator elements from four dimensions.

Coupled with the features of the indicator system mentioned above, we use AHP to determine the weighted indicator weights at three levels. We conducted a survey and invited 10 scholars and experts engaged in research on the core competitiveness of China's aerospace enterprises to increase the validity of survey. Judgment matrix construction was conducted from four dimensions, i.e. resource capacity, technical capacity, product capacity and environment capacity, with consistent judgment matrices finally obtained after three rounds of negotiations among the 10 
invited experts.

Based on the importance of each influencing factor, we can sort the core competitiveness of aerospace enterprises from a dual-capacity perspective, as shown in Table 1

The principle based on which we select the factors influencing the core competitiveness of aerospace enterprises is that the indicators with the calculation result being smaller than 0.1 will be eliminated and such indicators are not considered as the factors influencing the core competitiveness of aerospace enterprises.

Based on the principle above, five influencing factors i.e. fund management capacity $\left(\mathrm{R}_{2}\right)$, renewable resource utilization $\left(\mathrm{R}_{3}\right)$, technical $R \& D$ cycle $\left(T_{2}\right)$, enterprise cost reduction rate $\left(\mathrm{P}_{2}\right)$ and industry external environment $\left(\mathrm{E}_{3}\right)$, will be eliminated.

Finally, through empirical research, an indicator system for 8 influencing factors is designed, with specific simplified indicators as shown in Table 2.

Table 1 Summary of importance (weight) of influencing factors

\begin{tabular}{|c|c|c|c|}
\hline Name of Secondary Indicators & Indicator Symbol & Weight & Whether Retain \\
\hline Human Resources & $\mathrm{R}_{1}$ & 0.45 & Yes \\
\hline Fund Management Capacity & $\mathrm{R}_{2}$ & 0.05 & No \\
\hline Renewable Resource Utilization & $\mathrm{R}_{3}$ & 0.05 & Yes \\
\hline Market Resource & $\mathrm{R}_{4}$ & 0.45 & Yes \\
\hline Technical Innovation Capacity & $\mathrm{T}_{1}$ & 0.5000 & Yo \\
\hline Technical R\&D Cycle & $\mathrm{T}_{2}$ & 0.0625 & Yes \\
\hline Cooperative Research Capacity & $\mathrm{T}_{3}$ & 0.4375 & No \\
\hline Product Features & $\mathrm{P}_{1}$ & 0.5000 & Yes \\
\hline Enterprise Cost Reduction Rate & $\mathrm{P}_{2}$ & 0.0625 & Yes \\
\hline Market Share & $\mathrm{P}_{3}$ & 0.4375 & No \\
\hline Enterprise Internal Environment & $\mathrm{E}_{1}$ & 0.4445 & \\
\hline Macro External Environment & $\mathrm{E}_{2}$ & 0.5000 & \\
\hline Industry External Environment & $\mathrm{E}_{3}$ & 0.0555 & \\
\hline
\end{tabular}

Table 2 Evaluation indicator system for selected factors influencing the core competitiveness of aerospace enterprises from a dual-capacity perspective

\begin{tabular}{|c|c|c|c|}
\hline & Primary Indicator & Secondary Indicator & $\begin{array}{c}\text { Attribute of } \\
\text { Secondary Indicator }\end{array}$ \\
\hline \multirow{4}{*}{$\begin{array}{l}\text { Evaluation indicator } \\
\text { system for factor } \\
\text { influencing the core } \\
\text { competitiveness of } \\
\text { aerospace enterprises } \\
\text { from a dual-capacity } \\
\text { perspective }\end{array}$} & Resource Capacity & $\begin{array}{l}\text { Human Resources } \\
\text { Market Resources }\end{array}$ & $\begin{array}{l}\text { Internal Capacity } \\
\text { External Capacity }\end{array}$ \\
\hline & Technical Capacity & $\begin{array}{l}\text { Technical Innovation Capacity } \\
\text { Cooperative Capacity }\end{array}$ & $\begin{array}{l}\text { Internal Capacity } \\
\text { External Capacity }\end{array}$ \\
\hline & Product Capacity & $\begin{array}{l}\text { Production Features } \\
\text { Market Share }\end{array}$ & $\begin{array}{l}\text { Internal Capacity } \\
\text { External Capacity }\end{array}$ \\
\hline & Environment Capacity & $\begin{array}{l}\text { Enterprise Internal } \\
\text { Environment } \\
\text { Macro External Environment }\end{array}$ & $\begin{array}{l}\text { Internal Capacity } \\
\text { External Capacity }\end{array}$ \\
\hline
\end{tabular}

\section{Conclusion}

Through comprehensive analysis of Chinese and foreign literature on the core competitiveness of aerospace enterprises, the factors influencing the core competitiveness of aerospace enterprises in China are summarized, followed by the analysis made based on such elements as the resource capacity, technical capacity, product capacity and environment capacity of aerospace enterprises. 


\section{(1) Resource capacity}

First, in terms of talent resources, in the current development situation, aerospace enterprises need to more innovative talents to meet their further development needs. Those that own such talents can obtain the most powerful core competitiveness and maintain strong competitive advantages in the fierce competition at home and abroad. Second, in terms of market resources, market resources are very important for the development of external capacity of aerospace enterprises and the elevation of their core competitiveness, and can realize the added value of aerospace enterprises and raise their position and influence in the markets at home and abroad at the same time. Particularly, the brand resources in the market resources are essential for China's aerospace enterprises to obtain core competitive advantages and can help them obtain more attention, attract a wider range of consumer groups, establish their own brand positions in the markets at home and abroad and realize long-term development.

(2) Technical capacity

The technical innovation capacity of aerospace enterprises has become the main force for them to obtain sustainable competitive advantages and form multiple core competitive powers, reflected by and contained in their representative products. Meanwhile, the $R \& D$ of aerospace products is complex system engineering and the result of nationwide cooperation and research based on collective wisdom. In the implementation process of the $R \& D$ of aerospace products, the management principle of aerospace enterprises is as follows: two overalls inside, middle outside, key parts in hand. The two overalls inside means that an aerospace enterprise is responsible for the overall design and overall integration of aerospace products, the key parts in hand means an aerospace enterprise must firmly grasp the key subsystems or key technology in its own hands and the middle outside means that an aerospace enterprise outsources general subsystems or general technical collaboration to external organizations and unitizes the high-quality resources and advanced technology of external research institutions to serve the enterprise. Such division of work and cooperation can not only guarantee the maximum benefits of the enterprise and ensure some benefits of external organizations, realizing cooperation, mutual benefits and joint development.

(3) Product capacity

Maintaining the development and core competitiveness of China's aerospace enterprises requires their good judgment of the market for their own products and good performance quality advantages, and what influence the development of the core competitiveness of aerospace enterprises is product capacity. The added value of products is the ultimate reliance of the added value of the core competitiveness of aerospace enterprises. Competitive advantages have unique performance and cost competitiveness, and high-quality products ultimately depend on products creating value for consumers and meeting market demands. If the products manufactured by an enterprise are not competitive, such products will not have any value in actual use.

(4) Environment Capacity

The main environment capacity of the development of aerospace enterprises is divided into internal environment capacity and external environment capacity. The external environment capacity not only provides opportunities that can be used by China's aerospace enterprises for the development of their core competitiveness but also pose certain threats to the development of their core competitiveness. Whether China's aerospace enterprises can use some opportunities to avoid possible threats mainly lies in aerospace enterprises' own conditions. Internal conditions are not only the basis and premise for the proposal of aerospace enterprises' development strategies but also a powerful guarantee of their core competitiveness enhancement. Aerospace enterprises are high-tech enterprises and involve many new independent intellectual property rights, which make the protection of such intellectual property rights an issue worth considering. Intellectual property protection refers to the extent to which the country protects the intellectual property of a certain 
aerospace enterprise. In the case of the country's strong protection of the enterprise's intellectual property, it will greatly promote the enterprise's technical innovation and enables the enterprise to obtain better technical output.

\section{References}

[1]Yanyan Zang.(2008) A Company Takes Human Resource as Basic Core Competition Formation. International Business Research, 11:23-25.

[2]Xiaolin Chen.(2009) A Comprehensive Evaluation Analysis of Financial Core Competitiveness of Listed Companies. International Journal of Financial Research , 12:89-94.

[3]Zhibin Liu.(2012) A Hybrid Optimization Algorithm to Evaluate the CCWPE Based on DEA Sampled by FCE. Journal of Computers, 11:2836-2841.

[4]Hengqing Tong, Yang Ye, Yichao Pan.(2010) Analysis and Evaluation for Core Competence of Insurance Company Based on SEM. Journal of Management , 3: 178- 182.

[5]Sabah Agha.(2011) Effect of Core Competence on Competitive Advantage and Organizational Performance. International Journal of Business and Management, 5:192-204.

[6]I.P.S. Ahuja.(2011) Managing Research and Development for Core Competence Building in an Organiza- tion. Journal of Technology Management \& Innovation. 9:122-124.

[7]Dougherty, Deborah, Helena, Danielle,.(2010) Exploring the Everyday Dynamics of Dynamic Capabilities. International Journal of Business and Management, 4:102-109.

[8]Brown, J. R., Day, R. L.(1981) Measures of manifest conflict in distribution channels. Journal of Marketing Research. 18:263-274.

[9]Rahab, Najmudin, Istiqomah.(2013) Local Economic Development Strategy Based on Local industrial Core Competence. International Journal of Business and Management, 3: 41-47.

[10]Andrew O Agbada.(2013) Core Competences and Optimising Bank Capital Management in Nigeria. International Journal of Financial Research, 1:75-83.

[11]TANG Weiwei1, SUN Jianping.(2008) Research on Enterprise Core Competence and Managerial Human Resource Strategy. Management Science and Engineering, 5:56-67.

[12]Qin Li, Xin Li \& Ping Zhou.(2010) The Strategic Choice of Core Competitiveness in Power Generating Enterprises: Knowledge Management. International Journal of Business and Management, 6:195-200.

[13]Bernard J. van Nieuwenhuyzen.(2009) Financial Literacy as Core Competency of South African Military Officers: A Measurement Instrument. Management Science and Engineering, 11:124-126.

[14]Aghion, P., Bloom, N., Blundell, R., Griffith, R..(2002) Competition and Innovation: An Inverted U Relationship. NBER Working Paper, 6: 92- 96.

[15]Aghion, P., Harris, C., Howitt, P., Vickers, J..(2001) Competition, Imitation and Growth with Step-by-Step Innovation. Rev. Econ. Study., 3: 467-492. 